Amaltea. Revista de mitocrítica

ISSN-e: 1989-1709

http://dx.doi.org/10.5209/AMAL.55213

\title{
Entrevista com Júlio Bressane
}

\author{
Cláudia Malheiros Munhoz ${ }^{1}$
}

Recibido: 08 de febrero de 2017 / Aceptado: 15 de febrero de 2017 / Publicado: 15 de octubre de 2017

Cómo citar: Malheiros Munhoz, C. (2017). Entrevista com Júlio Bressane. Amaltea. Revista de mitocrítica, 9, 2017, 61-64.

\section{Como se originou o seu interesse por mitologia?}

Não saberia dizer exatamente, porque as narrativas mitológicas foram talvez as primeiras leituras, não que eu fiz, mas que ouvi. Quando ainda pequeno, tinha uma tia que lia pra mim e eu ouvia muitas narrativas. Ela era uma mulher que gostava muito de ler essas histórias pra mim. Depois, li algumas dessas narrativas, mas o que me chamou mais a atenção foi um livro do Roland Barthes que se chama Mitologias, um livro de 57 ou 56, mas que eu só li dez anos depois, em 67, e foi ali que entendi a questão do que interessa na mitologia, o que tem de lastro do mito no tempo, e como é que isso se transforma, como uma mitologia, um tipo de orientação de estado de espírito, se transforma nessas coisas de hoje. A mitologia do Barthes é um carro Citroen, um novo modelo que foi lançado, que ele diz até algo muito curioso: que os franceses, quando viam aquele carro que acabava de sair, não acreditavam, achavam que era algo mágico, caído do céu, como um conto do Voltaire. Então foi ali que eu comecei a me interessar por isso.

A mitologia me veio também muito pela pintura. Um dos últimos filmes que eu fiz, por exemplo, o Educação Sentimental, toda a mitologia do Endimião me veio pela pintura. Há um filme do Chaplin, que também estudei muito, chamado Monsieur Verdoux - inclusive na Erva do rato tem uma cena do Monsieur Verdoux, um diálogo em que uma mulher diz do amor dela: "Ele era tudo pra mim. Ele era inválido, e eu que tomava conta dele. Ele era uma religião, se eu tivesse que matar por ele, eu matava". Isso está no Monsieur Verdoux, e eu o pus na Erva do rato. Eu vi muitas vezes o Monsieur Verdoux, o filme é de 1946, e ali tem a primeira grande menção ao mito do Endimião. Ele fala "eu estou aqui vendo a lua, como Endimião". E vi esse mito na pintura, tem muitos que representam isso. Sobretudo um que me chamou muito a atenção, porque foi o primeiro que me apareceu como evidência, que é um quadro que está no Louvre - um museu que sempre frequentei muito e até hoje frequento -, e tem ali um quadro de Anne Trioson que representa o Endimião: a lua está oculta,

\footnotetext{
Universidad Complutense de Madrid. claumm88@gmail.com http://orcid.org/0000-0002-7126-1422
} 
mas tem um cupido abrindo uma parte da ramagem, e a luz da lua está entrando e iluminando o Endimião. Foi o primeiro quadro que estudei para fazer o Educação Sentimental. É só um exemplo, tem também a Cleópatra, e mesmo São Gerônimo. Nós fizemos um estudo do São Gerônimo e da Cleópatra através da pintura.

Então a mitologia me veio muito pela pintura, e uma certa mitologia pela música. E também, é evidente, li. Li um extraordinário livro de Robert Graves que se chama Mitos gregos. Um livro capital para quem ainda pretende escrever uma história, ou fazer alguma trama, porque ali estão feitas todas as combinações possíveis. Então foi aqui e ali, sempre lendo alguma coisa. Gosto muito de dicionários, tem um dicionário de mitos também que estudei. Enfim, os filmes eu faço por razões muito intuitivas, mais que por um programa cerebral. Vou vendo o que tinha no mito de atraente e que eu podia sentir de uma maneira melhor, e foi isso, seja o Endimião, seja São Gerônimo, seja Cleópatra, tudo me veio assim muito como uma maneira encantada de ouvir um relato. O mito também é uma maneira de sentir o mundo, é um sentimento do mundo.

Sobre o filme Cleópatra, você comentou, numa sessão do festival de cinema Filmadrid, que não estava excessivamente preocupado com uma precisão histórica em relação ao cenário, por exemplo. Quais eram suas preocupações na transposição desse mito para o cinema?

O filme da Cleópatra é extremamente preciso do ponto de vista textual, da fonte original do mito que é o texto do Plutarco - que tem a vida do Júlio César, em que a Cleópatra ocupa umas 4 ou 5 páginas, talvez, e a vida do Marco Antônio, onde ela ocupa 10 ou 15 páginas -, e Antônio e Cleópatra do Shakespeare. Essas foram minhas fontes. Isso do ponto de vista, digamos, do entrecho do mito, do enredo do mito. Por outro lado, eu dei uma plasticidade a isso dentro da pintura e dentro de uma concepção de construção da imagem a partir da língua portuguesa. O texto da Cleópatra que coloquei ali, isso sim, é um texto inventado, porque eu fiz uma espécie de seleção de sintagmas, frases, palavras e versos da língua portuguesa que pudessem estar dentro daquela trama da vida da Cleópatra. Inclusive, acrescentei coisas que não estão presentes em nenhuma outra versão do mito: a parte da Cleópatra depois da morte do Marco Antônio, os 5 anos que ela viveu depois da morte dele, em que ela se despersonalizou. Esta frase é dela "Eu vou morrer sem morrer". Ela se despersonalizou, transformou o corpo, se martirizou, se flagelou nesse mausoléu onde ela se enclausurou. Nenhum filme sobre a Cleópatra menciona isso, esse foi o primeiro. E uma outra coisa que também foi recente, e isso eu vi divulgado em revistas: encontraram uma caixa com tábuas de comércio da época da Cleópatra, feita durante seu reinado, de solidariedade, de abrigo e proteção aos judeus. Ela queria protegê-los e criou para eles uma parte da distribuição gratuita de trigo, deu uma parte dessa colheita de graça para sustentar os judeus. Ela foi uma menina muito talentosa, muito inteligente, feiosa, e foi criada dentro da biblioteca da Alexandria, dentro do museu, onde ela aprendeu línguas, leu os clássicos etc. Sobretudo, em um lugar com grandes leitores. O importante - deveria ser assim até hoje, mas não é, infelizmente - é ler, e não escrever; escrever não tem importância, tudo já foi escrito. O importante é ler, mas, desgraçadamente, quem lê acaba escrevendo. Ela foi uma mulher educada e aprendeu com os grandes mestres leitores da biblioteca de Alexandria, que eram todos judeus. Então ela tinha uma ligação muito afetiva e de confiança com os judeus, uma leitora como ela, uma mulher inteligente, sabia de onde aquilo vinha. 
Mais tarde, já rainha, ela fez essa lei de proteção, abrigo e de ajuda aos judeus. Isso não foi mencionado em nenhum filme dela, e nem poderia ter sido, porque foi uma descoberta dos anos 90. E eu coloquei isso no filme. Então o filme tem uma verdade, digamos, histórica, de acontecimentos, gestos, e ações da Cleópatra muito grande, apesar de ser uma ficção quanto à parte falada, porque os diálogos e os textos são textos de poesia e de literatura portuguesa, para que a língua influenciasse na criação da imagem numa versão em português.

\section{O que o motivou a criar essa versão do mito da Cleópatra dentro da cultura brasileira, em língua portuguesa?}

O fato de não existir nada assim. Sobre a Cleópatra, há um verso do Camões que cita o seu nome, e um soneto do Bilac que fala sobre ela (quando ela abre os olhos, ela estava dormindo), mas são escassas as referências. Não existe a Cleópatra em português, não foi um mito apropriado, como não existe o São Gerônimo. Então foram coisas que eu achei que esse extra-brasileiro, extra-Brasil, era importante que entrasse na nossa circulação, e que não tivéssemos essa timidez cultural de nos aproximarmos e nos apropriarmos de um mito. Essas são as razões conscientes, mas as razões que o levam a fazer algo são forças inconscientes. Às vezes, você imagina que sabe, mas não sabe; imagina que seja por um motivo, mas são razões que você desconhece. O que o leva a fazer algo é muito difícil localizar o por quê, há razões que você dá, como "trazer para a cultura um mito desconhecido etc.". Essas são as evidências, mas há uma coisa mais forte e profunda que você ignora e que vem para você, uma coisa banal, que passa quase desapercebida e é aquilo que o motivou. A razão consciente é exatamente essa ausência, e trazer para a cultura brasileira alguma coisa de fora daquela cultura, fora daquele "paideumazinho" já escolhido ali. Em princípio, foram essas razões, que são débeis e fracas como porquê, mas até onde você pode confessar, porque talvez sejam razões inconfessáveis. Não só no sentido de que possa ter uma certa inibição de falar, mas também de não saber se é essa mesmo a razão.

Falando sobre o Padre Antônio Vieira, você comentou a perda das culturas indígenas no Brasil. No Macunaíma, do Mário de Andrade, tem um esforço por recuperar alguns mitos amazônicos e misturá-los com mitos europeus. Nos seus filmes, nós vemos também a música popular brasileira, o carnaval, misturados com trechos de filmes europeus, e inclusive com mitologia grega. Qual você acha que foi o resultado disso no imaginário do brasileiro e na sua relação com a mitologia clássica e os mitos indígenas e africanos?

Não sei até que ponto há uma consciência disso, mas há uma sensação muito grande, que todos sentem, do passado americano. Isso está muito vivo em nós, nos gestos, em alguns costumes, mesmo que se ignore exatamente o que foi isso. E a questão da contribuição, isso já foi feito por muita gente, era aquilo que o Oswald chamava de "contribuição milionária de todos os erros", todas essas palavras, todos esses vocábulos, todos esses gestos, essas expressões, esses procedimentos, essa culinária, tudo isso do homem antigo e dos mitos antigos americanos está muito vivo entre nós, apesar de oculto, apesar de não conscientemente tratar disso, mas isso está dentro de nós e, desgraçadamente, muito abafado e adormecido. Mas acho que há uma literatura, uma antropologia no Brasil desde os anos 10 ou 20, que foi pouco a pouco construindo um grande território onde isso está tudo dividido. Inclusive o próprio Mario de Andrade se valeu de um célebre estudo de Koch-Grünberg, foi dali 
que ele tirou o mito do Macunaíma, e acho que isso tudo faz parte de uma literatura. Se houver algo lá na frente, faz parte de um espécie de porvir, de um pensamento, de uma forma de linguagem, de uma aquisição de conhecimento e de autoconhecimento que é indispensável. Tudo isso está dentro de nós. Tem o Vieira, também antes do Vieira, antes dele, muitíssimo, depois dele, pouca coisa. Mas o próprio Vieira se deu conta disso, do tamanho desse, digamos, continente submerso, que é a América antiga.

\section{Quais mitos você considera que continuam sendo atuais?}

Todos os mitos são atuais e todos os mitos são relevantes para qualquer cultura. $\mathrm{O}$ problema é encontrar o mito e encontrar onde colocá-lo. Todos os mitos são os ossos da humanidade, e todos os ossos são importantes. Você pode construir um corpo faltando o rádio, o fêmur, o externo, pode faltar um ou outro osso, mas vai faltar, porque o esqueleto pede os ossos todos. Os mitos são a ossatura da humanidade, e todos os ossos são importantes. Não há nenhum mito que não seja importante, mesmo os mitos mais esquecidos, os mais distantes, os mais obscuros, os menores, um mito do norte do Laos, um mito da Grécia Antiga, um mito da América Antiga, tudo isso faz parte dessa grande ossatura do imaginário humano. Todos os mitos são importantes e recorrentes no meu sentir. 